\title{
HETEROGENEITY OF WHEAT ENDOSPERM PROTEOLIPIDS (CM PROTEINS)
}

\author{
M. A. Rodriguez-Loperena, C. Aragoncillo, Pilar Carbonero and F. Garcia-Olmedo \\ Departamento de Bioquimica. Universidad Politécnica. E.T.S. Ingenieros Agrónomos. Madrid-3, Spain
}

Key Word Index-Triticun aestioum; Triticum durum; Aegilops squarmosa; Gramineae; wheat; proteolipids; CM proteins; gliadins; albumins; electrofocusing; electrophoresis.

\begin{abstract}
Proteins extracted with $\mathrm{CHCl}_{3}-\mathrm{MeOH}$ from wheat endosperm have been fractionated by Sephadex G-100 and the $15000-20000 \mathrm{MW}$ range fraction, designated CM protein, has been examined by combined electrofocusing ( $\mathrm{pH}$ range $5-8$ ) and electrophoresis $(\mathrm{pH} 3 \cdot 2)$ and the heterogeneity of the electrophoretic components has been ascertained. It has been shown by joint mapping and by sequential extraction that $\mathrm{CM}$ proteins are extracted by $70 \% \mathrm{EtOH}$ but not by $\mathrm{H}_{2} \mathrm{O}$, although they can be made water-soluble after dialysis against an acid buffer, pH $3 \cdot 2,3 \mathrm{M}$ urea, without losing their solubility in $\mathrm{CHCl}_{3}-\mathrm{MeOH}$ mixtures. It is concluded that $\mathrm{CM}$ proteins fit the definition of a Folch-Lees proteolipid. The Triticum aestivum (genomes A BD) map can be reconstructed by mixing $T$. durum (AB) and Aegilops squarrosa (D). The low intragenomic variability of $\mathrm{CM}$ protein is confirmed.
\end{abstract}

\section{INTRODUCTION}

The electrophoretic patterns ( $\mathrm{pH} 3 \cdot 2$ ) of $\mathrm{CHCl}_{3}-$ $\mathrm{MeOH}(2: 1, \mathrm{v} / \mathrm{v})$ extracts of partially delipidated endosperm from Triticum aestivum $\mathrm{L}$. consistently show three fast main bands, CM1, CM2 and CM3, and those of $T$. durum Desf. only two, CM2 and CM3 [1]. Garcia-Olmedo and Carbonero [2] purified and partially characterized CMI and CM2, showing that they were controlled by chromosomes 7D and 7B respectively. The third component, CM3, has been recently purified by Redman and Ewart [3] and by Aragoncillo [4]. The latter has also purified a faster variant of $\mathrm{CM} 3$, designated CM $3^{\prime}$, which is present only in a few $T$. durum varieties.

There is indirect evidence that more than one protein might be present in band $\mathrm{CM} 3$ of $T$. aestitum (genomes ABD): (i) both Aegilops squarrosa (D) and $T$. durum (AB) have a CM 3 band [4]; (ii) the $\mathrm{CM} 3 / \mathrm{CM} 2$ and $\mathrm{CM} 3 / \mathrm{CM} 1$ ratios, which are rather constant within the species, are significantly depressed in both ditelosomics and in the monosomic of chromosome $4 \mathrm{~A}$, but no suppression of CM3 takes place [4]; (iii) amino acid analysis of $\mathrm{CM}$ proteins purified by ion exchange [3] and by direct elution of trichloroacetic acid precipitated bands from an acrylamide slab show a considerable lack of agreement [4].

The electrophoretic patterns ( $\mathrm{pH} 3 \cdot 2$ ) of wheat endosperm proteins extracted with $70 \%$ ethanol $(\mathrm{EtOH})$ have a number of components migrating ahead of gliadins which are of great taxonomic significance, as shown by Johnson and co-workers [ 5 7]. Waines [8] has recently implicated homoeologous chromosome groups 4 and 7 in the control of some of these proteins. CM proteins are soluble in $70 \%$ EtOH and the three variant patterns, CMICM2-CM3, CM2-CM3, and CM2-CM3', can be recognized among the more complex patterns of EtOH-extracted proteins $[3,4]$. It has also been observed that these proteins are at least partially soluble in water $[3,4]$.

We report here an investigation of the heterogeneity of $\mathrm{CM}$ proteins and their relationship with the $70 \% \mathrm{EtOH}$ and $\mathrm{H}_{2} \mathrm{O}$-extracted proteins.

\section{RESULTS}

\section{Gel filtration}

Proteins extracted with chloroform-methanol $\left(\mathrm{CHCl}_{3}-\mathrm{MeOH}\right)(2: 1)$ from partially delipidated 
Table 1. Distribution of map components in different protein preparations*

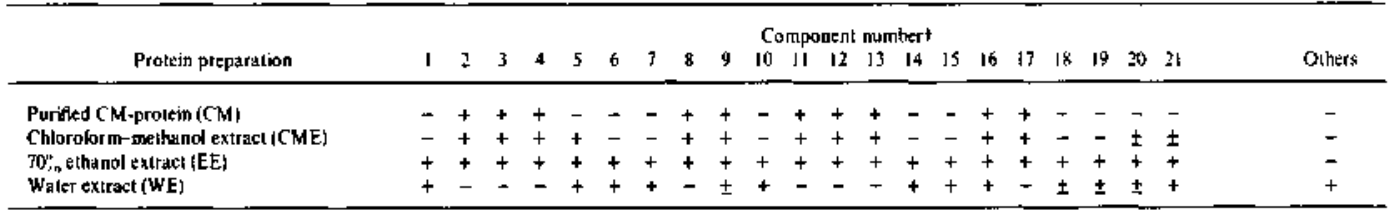

- + , Present; - absent; \pm , detected at the overloading level.

† See Fig. 2.

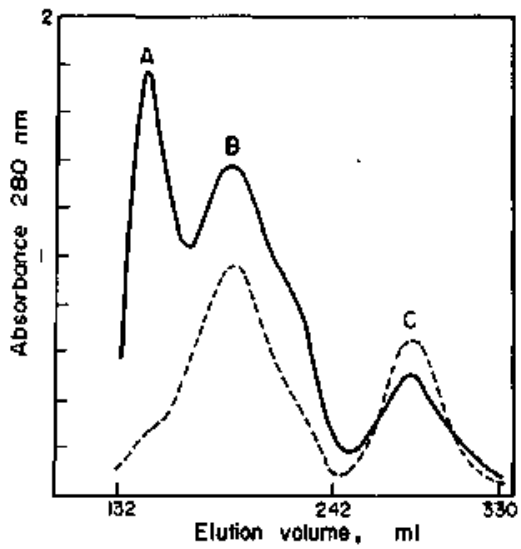

Fig. L. Sephadex G-100 gel filtration profile of extracts. Crude $\mathrm{CHCl}-\mathrm{MeOH}_{3}$ extract (- - ) and the same extract after dialysis. centrifugation and freeze drying of the supermatant (--). Peak

$A$ are glutenins, peak B gliadins and peak C CM-proteins.

wheat endosperm can be fractionated on Sephadex G-100(Fig. 1). Three fractions are obtained: peak A, which appears with the exclusion volume, is precipitated by dialysis against water and is probably composed of glutenins; peak $B$ elutes in the 40000-60000 MW range and yields an electro-

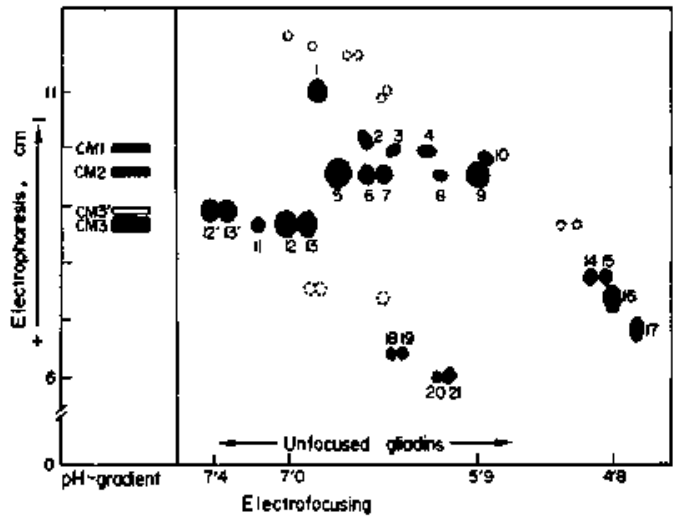

Fig. 2. Composite map obtained by combined electrofocusing and electrophoresis of protein extracts. Spots shown in broken line represent components extracted only with water (A com. ponents). phoretic pattern identical with that of the classical gliadins extracted with $70 \% \mathrm{E} / \mathrm{OH}$; and peak C, which is eluted in $15000-20000 \mathrm{MW}$ range, consists of the CM proteins. Proteins extracted with $70 \% \mathrm{EtOH}$ or with water also yield a peak in the same range as peak $\mathrm{C}$, which includes the proteins that move ahead of gliadins in electrophoresis at pH $3 \cdot 2[9,10]$.

\section{Combined electrofocusing and electrophoresis}

Two-dimensional mapping by combined gel electrofocusing and electrophoresis was carried out at optimal and at overloading concentrations of the following protein preparations: peak $\mathrm{C}$ (CM), $\mathrm{CHCl}_{3}-\mathrm{MeOH}$ extract (CME). $70 \% \mathrm{EtOH}$ extract (EE) and water extract (WE). Binary mixtures of these extracts were also run to confirm homology of spots. A composite map for $T$. aestivum var. Chinese Spring is presented in Fig. 2 and the observed distribution of components in the different preparations is summarized in Table 1. Densitometric profiles of the three latter types of preparation from $T$. aestium var. Candeal are superposed in Fig. 3. Maps of CM and CME have

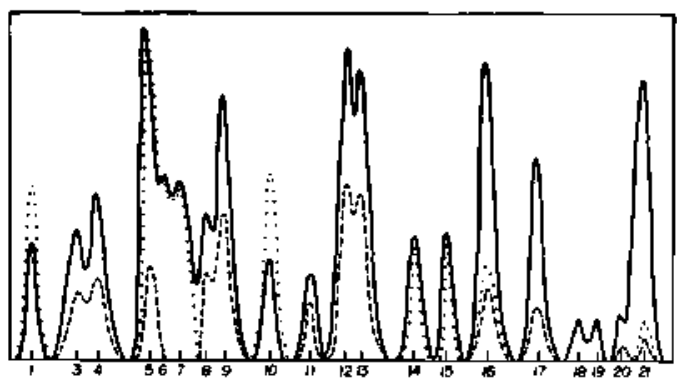

Fig. 3. Densitograms of maps obtained with diflerent protein preparation of Triticum aesrioum var. Candeal. Spot numbers are those given in Fig. $2 . \mathrm{EE}, 70^{\circ} ; \mathrm{ElOH}$ extract (-); WE. water extract $(\cdots \cdots)$; $\mathrm{CME}, \mathrm{CHCl}_{3}-\mathrm{MeOH}$ extract (--) . All three extracts were obtained from the same amount of endo. sperm (25 mg). The CM protein densitogram. at the appropriate scale, was identical with that of CME but without peaks $S$, 10 and 21 . 
the same components in the zone of faster electrophoretic migration, with the exception of component 5 and the traces of 20 and 21 which are missing from $\mathrm{CM}$.

All CME components are extracted more readily with $70 \%$ EtOH: spots $2,3,4,8,9,11,12$ and 13 in the CME map have $50-70 \%$ of the intensity of those in the EE map while spots $5,16,17$, 20 and 21 in the CME map have $5-20 \%$ of the intensity; components 1, 6, 7, 10,14, 15, 18 and 19 are only present in the EE map. These results are consistent with those obtained by sequential extraction. Extraction with $\mathrm{CHCl}_{3}-\mathrm{MeOH}$ after $70 \% \mathrm{EtOH}$ yields none of the components of the CME map, while extraction with $70 \%$ EtOH after

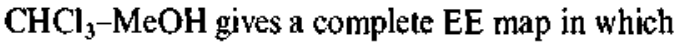
spots $2,3,4,8,9,11,12$ and 13 are much weakened.

The WE map has 9 components in common with the EE map (spots 1, 5-7, 10, 14-16 and 21). Some of these, 14-16 and 21, are extracted more effectively with $70 \% \mathrm{EtOH}$ than with water. In addition WE has a number of components, designated A in Fig. 2, which are not detected in ejther $\mathrm{CME}$ or EE. Extraction with water after $70 \%$ EtOH yields only the A components plus spots 1 and 10 . The map obtained with the $70 \% \mathrm{EtOH}$ extract of water extracted flour closely resembles that obtained with CM. Thus, water does not extract $C M$ proteins from flour. WE has two minor components overlapping with EE components $11-12$ but different from them as demonstrated in T. durum var. Ledesma, whose EE map lacks 11 and has a variant of 12 but whose WE map still has the two weak components in the same position as 11 and 12 .

Proteins extracted with $\mathrm{CHCl}_{3}-\mathrm{MeOH}$ from EE yield the same map as CME. CM proteins are readily soluble in $\mathrm{CHCl}_{3}-\mathrm{MeOH}$, in water and in $70 \%$ EtOH after gel filtration in acid buffer, $\mathrm{pH}$ $3 \cdot 2,3 \mathrm{M}$ urea, dialysis against water and freezedrying. However, water does not extract $\mathrm{CM}$ proteins from CME or EE.

\section{Analysis of tetraploid and hexaploid wheats}

In Table 2, CME and EE phenotypes of hexaploid wheats (genomes ABD) and tetraploid wheats (AB), as well as that of Aegilops squarrosa (D), are recorded. Equivalence of spots was ascertained by joint mapping. All hexaploids have the phenotype of variety Chinese Spring with few exceptions: component 2 is absent in six varielies, a variant pattern is obtained for components $18-21$ in two varieties, and some additional components are present in the synthetic $T$, spelta which are contributed by $T$. carthlicum.

All tetraploid phenotypes, natural as well as obtained by genome extraction, are identical, with the exception of variety Ledesma, which has components $12^{\prime}-13^{\prime}$ of different mobility and isoelectric points than 12-13, and the already mentioned additional components of $T$. carthlicum. All components of $T$. durum maps are recognized in $T$. aestivum maps.

Table 2. Distribution of map components in Aegilops squarrosa and several Triticum genotypes*

\begin{tabular}{|c|c|c|c|c|c|c|c|c|c|c|c|c|c|c|c|c|c|c|c|c|c|c|}
\hline \multirow[b]{2}{*}{ Sumpks } & \multirow[b]{2}{*}{1} & \multirow[b]{2}{*}{2} & \multirow[b]{2}{*}{3} & \multirow[b]{2}{*}{4} & \multirow[b]{2}{*}{$s$} & \multirow[b]{2}{*}{6} & \multirow[b]{2}{*}{7} & \multirow[b]{2}{*}{8} & \multirow[b]{2}{*}{9} & \multicolumn{5}{|c|}{ Component number ${ }^{\dagger}$} & \multirow{2}{*}{15} & \multirow[b]{2}{*}{16} & \multirow[b]{2}{*}{17} & \multirow[b]{2}{*}{18} & \multirow[b]{2}{*}{19} & \multirow[b]{2}{*}{20} & \multirow[b]{2}{*}{21} & \multirow[b]{2}{*}{ Others } \\
\hline & & & & & & & & & & 10 & ii & 12 & 13 & 14 & & & & & & & & \\
\hline \multicolumn{23}{|l|}{ Triikcum esesidyum var.: } \\
\hline Chitzese Spring & + & + & + & + & + & + & + & + & + & + & + & + & + & + & + & + & + & + & + & + & + & - \\
\hline Candeal & + & - & + & + & + & + & + & + & + & + & + & + & + & + & + & + & + & + & + & + & + & - \\
\hline Ptêlude & + & + & + & + & + & + & + & + & + & $?$ & + & + & + & + & + & + & + & + & + & 4 & + & - \\
\hline Rescue & + & - & + & + & + & + & + & + & + & + & + & + & + & + & + & + & + & + & + & + & + & - \\
\hline Thatcher & + & - & + & + & + & + & + & + & + & + & + & + & + & + & + & + & + & + & + & + & + & + \\
\hline Traquejos & + & - & + & + & + & + & + & + & + & + & + & + & + & + & + & + & + & $v$ & $v$ & $v$ & v & - \\
\hline Canalejas & + & - & + & + & + & + & + & + & + & + & + & + & + & + & + & + & + & v & $v$ & $v$ & $\checkmark$ & - \\
\hline Chamorro & $?$ & - & + & + & + & + & + & + & + & + & + & + & + & + & + & + & + & + & + & + & + & - \\
\hline Triskcunt sperles & + & - & + & + & + & + & + & + & + & + & + & + & + & + & + & + & + & + & + & + & + & + \\
\hline \multicolumn{23}{|c|}{ 然 } \\
\hline Senalore Capelli & - & - & - & - & - & + & + & + & + & $?$ & - & + & + & + & + & + & - & + & + & + & + & - \\
\hline Ledesma & - & - & - & - & - & + & + & + & + & $?$ & - & $v$ & $\mathbf{v}$ & + & + & + & - & + & + & + & + & - \\
\hline Telraprelude & - & + & - & - & - & + & + & + & + & $?$ & - & + & + & + & + & + & - & + & + & + & + & - \\
\hline Tetrarescue & - & - & - & - & - & + & + & + & + & $?$ & - & + & + & + & + & + & - & + & + & + & + & - \\
\hline Tetralhatcher & - & - & - & - & - & + & + & + & + & $?$ & - & + & + & + & + & + & - & + & + & + & + & + \\
\hline Triticum carthlicus & - & - & - & - & - & + & + & + & + & $?$ & - & + & + & + & + & + & - & + & + & + & + & + \\
\hline Atgilopx cepuerryoxd & + & - & + & + & + & - & - & - & - & - & + & + & + & - & - & - & + & + & + & + & + & + \\
\hline
\end{tabular}

* + , Present: -, absent; v, possible genetic variant present; ?, presence not unequivocally established.

$\uparrow$ See Fig. 2. 
All components of Ae. squarrosa maps are present in $T$. aestivum. Three of them, 12,13 and 20 are also present in $T$. durum.

\section{DISCUSSION}

\section{Heterogeneity of CM proteins}

The above results indicate that not only $\mathrm{CM} 3$ is heterogeneous, as suspected,but also other electrophoretic bands seem to yield more than one component.

The possibility of artifacts cannot be overlooked. These could arise during electrofocusing or in the previous handling of the protein preparations. Our unpublished genetic evidence permits discarding some of the potential cases of artifact formation: the genetic control of component 2 is independent from that of 3-4; gene(s) for component 5 are located in a different chromosome than those for $6-7$ and $8-9 ; 11$ is equally independent of 12-13; component 16 is controlled by a diflerent chromosome than 17 ; and the genetic variation of components $18-21$ precludes their being artifacts.

These considerations narrow the possibilities to the pairs $3-4,8-9,12-13$ and $12^{\prime}-13^{\prime}$, that could represent one protein each, and components 6,7 , 14 and 15 , that are controlled by the the same chromosome arm and could be diflerent modifications of the same protein.

Different electrofocusing conditions have been employed to investigate if these could alter the patterns: no significant changes were observed when persulfate was substituted by riboflavin in prepatation of the gel or when the sample was applied on top of the column instead of incorporated into the polymerization mixture.

It does not seem likely that the pairs are the result of incomplete delipidation because the prolonged exposure to acid during gel filtration and dialysis against water does not alter the pattern. However, they could represent in vivo modified forms of the same polypeptides. In this connection, it is particularly striking that the two components of $\mathrm{CM}^{\prime}, 12^{\prime}-13^{\prime}$, differ to the same extent in their isoelectric points and electrophoretic mobility from components 12-13 (CM3). In any case, the elucidation of this matter will depend on purification of the individual components or on further genetic studies.
In conclusion, CM3 and possibly CM1 and $\mathrm{CM} 2$ are heterogeneous, which would explain the already mentioned differences in the amino-acid composition data $[3,4]$.

\section{Classification of CM proteins as proteolipids}

Proteolipids were first isolated from brain tissue by Folch and Lees [11] and defined as proteins insoluble in water and aqueous solvents but soluble in $\mathrm{CHCl}_{3}-\mathrm{MeOH}$ mixtures. Although especjally abundant in nervous tissue, proteolipids are also widely distributed in animal and plant tissues [12]. Zill and Harmon [13] have reported on chloroplast proteolipids and Rohrlich and Niederauer [14] described a proteolipid from wheat endosperm, a non-photosynthetic plant tissue, which was recovered from the interface of the Folch wash of endosperm lipids extracted with $\mathrm{CHCl}_{3}-$ $\mathrm{MeOH}$. The $\mathrm{CM}$ proteins are readily soluble in $\mathrm{CHCl}_{3}-\mathrm{MeOH}(2: 1)$ and in water after gel filtration in acid buffer, dialysis against water and freeze-drying. In a similar manner, the Folch-Lees protein is still soluble in $\mathrm{CHCl}_{3}-\mathrm{MeOH}$ mixtures after it has been made water soluble by dialysis against solvents of increasing polarity, but is not water-soluble in its native state or when obtained by vacuum evaporation of the $\mathrm{CHCl}_{3}-\mathrm{MeOH}$ extraction mixture $[12,15]$. On this basis, $C M$ proteins should be classified as true proteolipids and not as intrinsic contaminants of gluten of the albumin type, as Meredith [16] tentatively classified a fraction, designated $\sigma$, obtained from the $\mathrm{CHCl}_{3}-\mathrm{MeOH}$ extract of gluten and probably equivalent to $\mathrm{CM}$ protein.

This proteolipid fraction is also a part of the socalled $[9,10,17-19]$ albumins plus globulins peak of gel filtration profiles of proteins extracted with $70 \% \mathrm{EtOH}$ and probably of similar gel filtration peaks from other extracts such as those obtained with $2 \mathrm{M}$ urea, diluted acids and aqueous alcohols.

\section{Low genetic variability of $C M$ proteins}

The present results confirm at much greater resolution the previous observation by one-dimensional electrophoresis of the low intragenomic variability of the non-gliadin $70 \% \mathrm{EtOH}$ proteins [5$7,20]$ and of the CM proteins [1]. The extreme usefulness of these proteins in phylogenetic studies, which has been extensively demonstrated by Johnson and coworkers, is based precisely on this pro- 
perty, which makes them good genomic markers. For the same reasons, these proteins should be excellent chromosome markers at the present degree of resolution.

The low genetic variability of these proteins is in sharp contrast with the great variability of gliadins recently observed by Wrigley and Shepherd [21] using combined electrolocusing and electrophoresis.

\section{EXPERIMENTAL}

Biological material. The following wheats were used in this study: Triticum aestizum varieties Chinese Spring. Candeal. Chamorro, Traquejos, Canaleja, Rescue. Thatcher and Ptelude: T. durtm varieties Senatore Capelli and Ledesma; T. corthlicum M-I; Aegilops squarrosa C-I; a synthetic T. speita (T. carthlicum $\times$ Ae. squarrosa) and the tetraploid versions of Rescue Thatcher and Prelude obtained by Kaltsikes st al. [22] by D genome extraction.

Exrracts. The crude $\mathrm{CHCl}-\mathrm{MeOH}$ (2:1) extract was obtained from delipidated flour as previously described [ 1$]$ and dispersed in $3 \mathrm{M}$ urea, dialysed against $\mathrm{H}_{2} \mathrm{O}$ for $48 \mathrm{hr}$, centri. fuged at $3000 \mathrm{~g}$ for $15 \mathrm{~min}$, and the supernatant freeze-dried.

For the mapping experiments, from 1/2 to 6 kernels were crushed between two metal plates with a hammer, defatled with light petrol $\left(50-70^{\circ}, 10 \mathrm{v} / \mathrm{w}\right)$ and the solvent removed in vacuo. The samples were extracted $3 x$ with the appropriate solvent ( $8 \mathrm{v} / \mathrm{w}$ each time) and the solvent of the combined extracts eliminated in vacuo or by freeze-drying. When sequential extractions were performed, after the third treatment with the first solvent $(100 \mathrm{v} / \mathrm{w})$, the solvent residues in the sample were removed in vacto and the second solvent then added.

Gel filtration. Both the crude and the dialysed $\mathrm{CHCl}_{3}-\mathrm{MeOH}$ extracts $(100-400 \mathrm{mg}$ of each) were subjected to gel filtration through Sephadex $\mathbf{G} \cdot 100(2.5 \times 90 \mathrm{~cm}$ column in aluminium lactate buffer 0. I M.pH 3.2, $3 \mathrm{M}$ urea. Fractions corresponding to peak $\mathrm{C}$ (Fig. I) were pooled, diajysed against $\mathrm{H}_{2} \mathrm{O}$ for $48 \mathrm{hr}$ and freeze-dried.

Coinhined electrofocusing and electraphoresis. The method described by Wrigley [23] was used with the following modifications: polyacrylamide gels were $2 \times 140 \mathrm{~mm}$. ampholine $\mathrm{pH}$ range 5-8, voltage was brought up to $470 \mathrm{~V}$ never exceeding $0.5 \mathrm{~mA} / \mathrm{tube}$ and then maintained for $6 \mathrm{hr} 30 \mathrm{~min}$, electrophor. esis time was $6 \mathrm{hr}$ at $10 \mathrm{~V} / \mathrm{cm}$. The unfixed electrofocused gel can be stored frozen for several days without affecting the two dimensional pattern. Under the above conditions, the gliadins are not focused and migrate very little into the starch gel. The $\mathrm{pH}$ gradient was determined according to Drysdale et al. [24].
Densitometry was performed in a Chromoscan (Joyce and Loebl) with the $620 \mathrm{~nm}$ filter. A wider sample holder was espe. cially made which allowed scanning of half a map each time.

Acknowletgenwents-We gratefully acknowledge samples given by Dt. P. J. Kaltsikes. Thjs work was carried out under contract with the Junta de Energia Nuclear. Spain.

\section{REFERENCES}

I. Garcia Olmedo, F. and Garcia Faure, R. (1969) Lebensm. Wiss. U. Technol. 2, 94.

2. Garcia Olmedo. F. and Carbonero, P. (1970) Phytochemistry 9, 1495.

3. Redman. D. G. and Ewart, J. A. D. (1973) J. Sci. Fd Agr 24,629 .

4. Aragoncillo, C. (1973) Dr. Ing. Agr. Thesis Poly1echnical University of Madrid.

5. Johnson, B. L. and Hall, O. (1965) Am. J. Botony 52, 506

6. Hall, O., Johnson. B. L. and Olered, R. (1966) Proc. 2nd int. Wheat Genetics Symp. Lund 1963, Hereditas. Suppl. Vol. 2, 47.

7. Johnson, B. L. (1972) Proc. Nat. Acad. Sci. U.S.A. 69, 1398

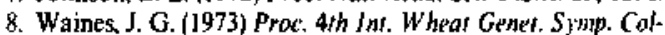
umbia [Sears. E. R. and Sears, L. M. S., Eds] (University of Missouri), pp. 873-877.

9. Huebner, F. R. and Rothfus. J. A. (197) Cereal Chem, 48. 469.

10. Charbonnier, L. (1973) Biochimic 55, 1217

11. Folch, J. and Lees, M. (1951) J. Biol. Chem. 191, 807.

12. Folch-Pi, J. and Stoffyn. P. J. (1972) Ann. N.Y. Acid. Sci. 195,86

13. Zill. L. P. and Harmon. E. A. (|96/) Biochim. Bioph's. Acia 53, 579 .

14. Rohrlich, M. and Niederauer, Th. (1967). Fette Seifon Anstrichnittel 69, 226.

15. Tennenbaum, D. and Folch-Pi, J. (1966) Biochim. Biophys. Acta 115, 141.

16. Meredith, P. (1965) Cereal Chem. 42, 149.

17. Jones, R. W., Babcock, G. E., Taylor, N, W. and Dimler, R. J. (1963) Certal Chem. 40, 409.

18. Meredith, O. B. and Wren, J. J. (1966) Cereal Chem. 43, 169.

19. Bietr, J. A. and Wall, J. S. (1972) Cereal Chem. 49,416.

20. Wajnes, J. G. (1969) PhD. Thesis, University of California, Riverside, Calit.

21. Wrigky, C. W. and Shepherd, K. W.(1973) Ann. N.Y. Acad. Sci. $209,154$.

22. Kaltsikes. P. J. Evans, L. E. and Bustuk, W. (1968) Science $159,211$.

23. Wrigley, C. W. (1970) Biochen. Genet. 4, 509 .

24. Drysdate, J. W. Righetti, P. and Bunn, H. F.(1971) Biochin. Biophys. Acta 229, 42. 